\title{
Vertical distribution of blue Shark (Prionace glauca) in The Indian Ocean
}

\author{
Fathur Rochman ${ }^{1, *}$, Gussasta Levi Arnenda ${ }^{1}$, Arief Wujdi ${ }^{1}$, and Roy Kurniawan ${ }^{1}$ \\ ${ }^{1}$ Research Institute For Tuna Fisheries, Bali, Indonesia
}

\begin{abstract}
Each fish species tends to choose a suitable environment suitable for its survival and reproduction horizontally and vertically. Blue shark (Prionace glauca) is the dominant catch of pelagic sharks by-catch in the Eastern Indian Ocean longline tuna fishery, with about $70 \%$ of the total sharks caught in this fisheries. This study aims to provide the information and the vertical analysis distribution of blue sharks based on temperature and depth in the Indian Ocean. The scientific observer collected 2,951 set-by-set longline fishing data based on Research Institute For Tuna Fisheries (RITF) from January 2006 to December 2018, on which the present analysis was made. The mini logger was used to measure the vertical distribution of blue sharks in the longline fisheries. This result indicated that blue shark was caught between 75.18-445.46 m depth, with $84 \%$ of which live at thermocline area (70-300 $\mathrm{m}$ depth), and $16 \%$ lived in underlayer area $(>300 \mathrm{~m}$ depth). Blue sharks distributed in the underlayer area have a larger body size than those in the thermocline area with a size $>180 \mathrm{cmFL}$ compared to $50-170 \mathrm{cmFL}$ in the thermocline area.
\end{abstract}

\section{Introduction}

The blue shark is a highly migratory species. Its range widely across many national boundaries and spending its time up to $92 \%$ in high seas makes it challenging to control and monitor [1]-[3]. The blue shark is by-catch species in longline tuna fisheries caught together with tuna species [3]-[5]. As a by-cath species in longline activity, the capture of blue sharks is unavoidable. It is difficult to release in the water; even if it can be done, it may not necessarily live again in nature due to injuries and stress during capture. A blue shark was the main catch of sharks, where blue shark dominates more than $60 \%$ of shark catches. It can be seen from the tabulation of catch data during the onboard observer program from 2006-2019 in this research data. The blue shark caught in the Indian Ocean is an incidental catch taken for fins, cutlets meat without ahead, and used and stored in a storage box [6], [7]. The use of blue sharks in the Indian Ocean is very different from that of the North Atlantic. [3], [8] reported that the discharged rate of blue sharks of the U.S and Canadian tuna fisheries approached $100 \%$ due to the non-commercial value of this species in North America. This information is a significant problem, and the current state of sharks includes those faced by the blue shark species in the Indian Ocean where this study was conducted.

\footnotetext{
* Corresponding author: fathur@kkp.go.id
} 
Blue sharks and other shark species have different characteristics from teleost species and tend to be closer to mammals, especially in terms of longevity, reproduction, low fecundity, and delayed sexual maturity [9]. Blue sharks reach adulthood at $220 \mathrm{~cm}$ at the age of 6 years, with the number of births per year is only 35 individuals with a gestation period of 12 months [3]. Despite this, the blue shark is considered the most prolific species among the elasmobranchs (productivity $r_{\max }$ 0.29) [9] and closer to bluefin tuna. Meanwhile, based on age on sexual maturity, it will take a long time to recover if the stock has been significantly degraded [10].

The distribution of blue sharks does occur horizontally and vertically following the desired depth and temperature of the waters where the availability of nutrients is met [11], [12]. Environmental factors from the surrounding waters significantly affect the horizontal and vertical distribution of fish or sharks in the ocean [11]. This research aims to provide information on the vertical analysis distribution of blue sharks based on temperature and depth in the Indian Ocean and retaliation with longline fisheries. It is hoped that this information can provide an overview of the scope of life of the blue shark so that it can be a reference in the capture and management of blue sharks in the future.

\section{Materials and methods}

\subsection{Study}

This research is a part of the Research Institute for Tuna Fisheries (RITF) scientific observer program from January 2006 to December 2018 . The area study covered $75.00^{\circ} \mathrm{E}-$ $131^{\circ} \mathrm{E}$ and $1.00^{\circ} \mathrm{S}-35^{\circ} \mathrm{S}$ of the Indian Ocean, from the west coast of Sumatra, south of Java/Bali /Nusa Tenggara, west of Australia, and east of Madagascar (Fig. 1). The scientific observation is carried out by participating in fishing activities based in four main ports, including Benoa (Bali), Cilacap (Central Java), Palabuhanratu (West Java), and Muara Baru (Jakarta). One hundred fifty-four ships were involved with 128 trips and 2,951 fishing sets of tuna longliners operated in the eastern Indian Ocean. The QGIS 3.16.2 Hannover was used for spatial data analysis where base map representation using Environmental Systems Research Institute (ESRI) standard map obtained from https://serve r.arcgisonline.com/ArcGIS/rest/services/World_Street_Map/MapServer/tile/ $\{\mathrm{z}\} /\{\mathrm{y}\} /\{\mathrm{x}\}$ an $\mathrm{d}$ the maritime boundaries geodatabase: naval boundaries and exclusive economic zone (20 $0 \mathrm{NM}$ ) version 7 obtained from https://www.marineregions.org/downloads.php as of 27 January 2021.

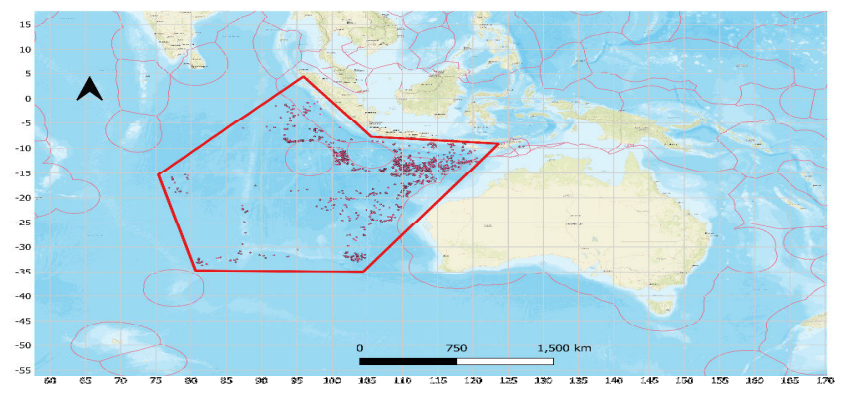

Fig. 1. Blue shark (BSH) catches coordinate in RITF scientific observer program 2006-2018 in the Eastern Indian Ocean (inside the red line) 


\subsection{Data analysis}

The research material is blue shark data which is the catch data of the RITF onboard observer program from January 2006 to December 2018. The data collected included catch species data, catch coordinates, longline tuna, and fishing line numbers. The swimming depth data of the blue shark was obtained from the validation of the mini logger data from 2007-2019. Minilogger is a device that uses recording data on fishing line depth and water temperature at a certain depth. The minilogger can record fishing depth data from 0 to 1200 $\mathrm{m}$ depth with an accuracy of 3.6 meters and a resolution of $36 \mathrm{~cm}$. Minilogger is also equipped with a temperature recorder with specifications from $-5^{\circ} \mathrm{C}$ to $35^{\circ} \mathrm{C}$. The type of minilogger used is the SP2T-1200 brand NKE Micrel with plastic and titanium raw materials ranging from 80 grams to 85 grams. There is three types of longline tuna research using mini logger device (2007-2019), among others are:

a. Surface Longline Type: consists of 1-5 fishing lines with a 92.23 to $180.81 \mathrm{~m}$ depth with a temperature of $21.84^{\circ} \mathrm{C}$ to $26.80^{\circ} \mathrm{C}$. This type of surface longline is used by ex. Taiwan boat until 2014

b. Mid Longline Type: consists of 1-12 fishing lines with a depth of 117.83 to 341.52 $\mathrm{m}$ with a temperature from $10.39^{\circ} \mathrm{C}$ to $21.83^{\circ} \mathrm{C}$. This type of mid-longline is widely used by Bagan Boat (North Sumatera).

c. Deep longline Type: consists of 1-18 fishing lines with a 75.18-445.46 $\mathrm{m}$ depth with a temperature of $9^{\circ} \mathrm{C}$ to $25.5^{\circ} \mathrm{C}$. The deep longline type is used by PT Samudera Indonesia, Inti Mas Surya, and other companies that catch tuna in the high seas.

The tabulation of the depth and temperature data from the mini logger research was then used to determine the swimming layer and water temperature. The blue sharks were caught using onboard observer data for 2006-2018.

\section{Results and discussion}

\subsection{Blue shark swimming layer and temperature}

The depth and temperature of the waters significantly affect the vertical distribution of fish and the vertical distribution of blue sharks. Temperature stratification at each depth dramatically affects the distribution of fish. It can be seen from previous studies conducted by [4] and [5]. This research indicated that the blue shark was caught at a depth of $75.18 \mathrm{~m}$ to $445.46 \mathrm{~m}$, with temperatures ranging from $9^{\circ} \mathrm{C}$ to $26^{\circ} \mathrm{C}$ (Figure 2). $84 \%$ of blue sharks caught in the thermocline area with a depth of 70 to $300 \mathrm{~m}$, while $16 \%$ are distributed slightly below the thermocline area up to a maximum $445.46 \mathrm{~m}$ depth. (Table 1).

Table 1. The number and CPUE (no. of fish/100 hooks) of blue sharks at depth and temperature strata of longliners in the Indian Ocean.

\begin{tabular}{cccccc}
\hline $\begin{array}{c}\text { Depth } \\
(\mathrm{m})\end{array}$ & $\begin{array}{c}\text { Temperature } \\
\left({ }^{\circ} \mathrm{C}\right)\end{array}$ & $\begin{array}{c}\text { Catch } \\
(\text { No. of Fish) }\end{array}$ & \multicolumn{3}{c}{ CPUE (no. of fish/100 hooks) } \\
\hline $0-100$ & 26 & 552 & 0.04 & 0.6 & max \\
$100-200$ & 20 & 531 & 0.04 & 1.38 & 0.14 \\
$200-300$ & 14 & 569 & 0.04 & 1.34 & 0.17 \\
$300-400$ & 11 & 239 & 0.04 & 1.37 & 0.18 \\
$>400$ & 9.5 & 74 & 0.04 & 0.54 & 0.13 \\
\hline
\end{tabular}




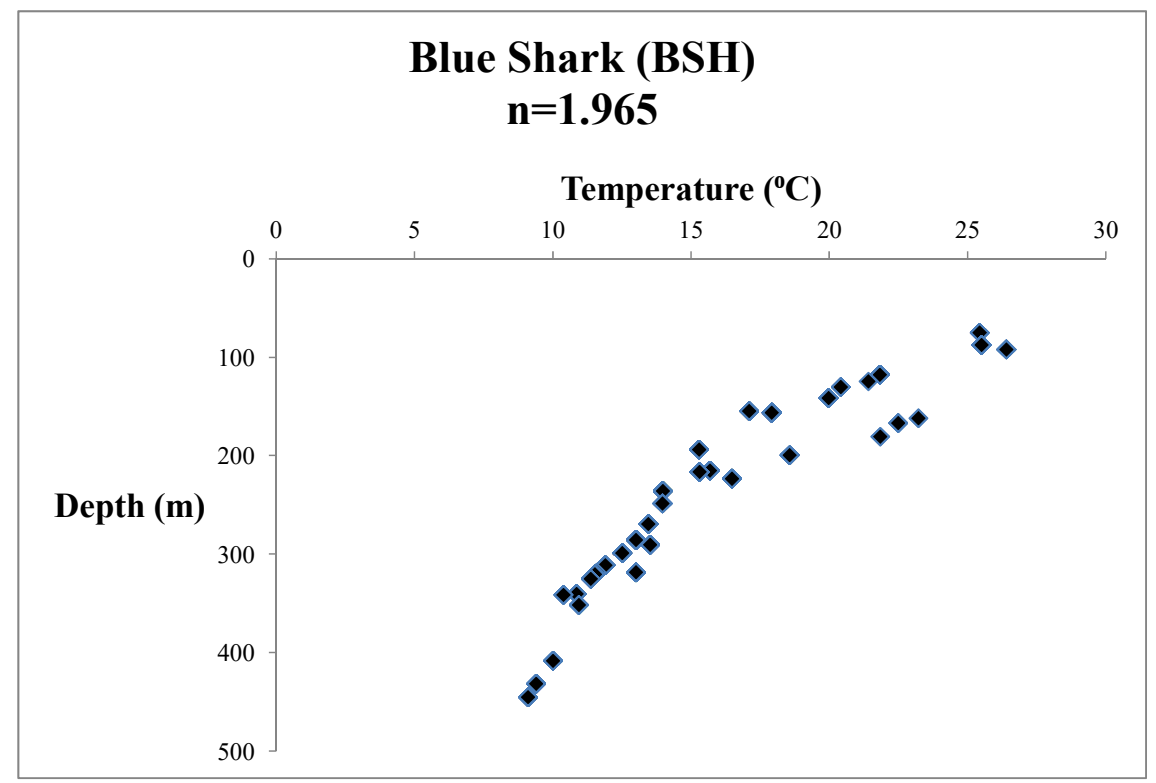

Fig. 2. Vertical distribution of blue shark $(\mathrm{BSH})$ based on depth $(\mathrm{m})$ and temperature $\left({ }^{\circ} \mathrm{C}\right)$ caught by longliner in the Indian Ocean

This study found that the vertical distribution of blue sharks was wider than several tuna species, with a distribution range of $75.18 \mathrm{~m}$ to $445.46 \mathrm{~m}$ and a depth temperature ranging from $9^{\circ} \mathrm{C}$ to $26^{\circ} \mathrm{C}$. Some tuna species such as yellowfin tuna, albacore, and southern bluefin tuna have vertical migrations from $35 \mathrm{~m}$ to $299 \mathrm{~m}$ with temperatures ranging from $11^{\circ} \mathrm{C}$ to $27^{\circ} \mathrm{C}$ [11], [12], [13]. The vertical distribution of blue sharks is almost the same as the vertical distribution of bigeye tuna with a swimming layer range between $92.23-470.12 \mathrm{~m}$ depth with almost the same temperature, between $8.35^{\circ} \mathrm{C}$ to $26.80^{\circ} \mathrm{C}$. However, a blue shark has an optimum thermocline area with a depth between $70 \mathrm{~m}$ to $300 \mathrm{~m}$ based on mini logger data (Table 2). Research using archival tags has revealed that some highly migratory and endothermic shark species can dive up to 1000 meters below sea level. Shortfin mako (Isurus Oxyrincus) distributed from $28 \mathrm{~m}$ to $866 \mathrm{~m}$ depth [14], oceanic whitetip shark (Carcharhinus longimanus) capable of reaching a depth of $1000 \mathrm{~m}$ [15], and salmon shark (Lamna ditropis) able to reach a depth of $968 \mathrm{~m}$ depth [16] and blue shark (Prionace glauca) can reach maximum $1160 \mathrm{~m}$ depth [17]. However, $90 \%$ of the activities are carried out in the thermocline area $(<300 \mathrm{~m}$ depth) with warmer temperatures and an abundance of prey [14]-[16].

The water layer consists of 3 layers: a homogeneous layer, a thermocline layer, and an underlayer. The homogeneous layer is characterized by relatively the same temperature at different depths, while the thermocline layer is characterized by a drastic drop in temperature and increasing depth. The underlayer is characterized by a shallow temperature but remains stable during increasing depth levels [18]. Tuna, tuna-like species, and the top predator such as blue sharks are retaliated against each other. These fish species are closely related to the thermocline layer [19] where this layer has a consistent temperature $\left( \pm 19^{\circ} \mathrm{C}\right)$, salinity ( $\pm 34.78 \mathrm{PSU})$, dissolve Oxygen $( \pm 4.68 \mathrm{ml} / \mathrm{l})$, and relatively good nutritional levels (Nitrate; $15.39 \mu \mathrm{mol} / 1$, Phosphate; $1.15 \mu \mathrm{mol} / 1$, Silicate; $21.80 \mu \mathrm{mol} / \mathrm{l}$ ) [12]. This results in high primary productivity and the availability of prey for blue sharks.

Blue sharks caught in the thermocline layer $(75-300 \mathrm{~m}$ ) have a size of 50-170 cmFL, while blue sharks caught below the thermocline layer have a larger size $(>180 \mathrm{cmFL})$. Blue sharks have negative buoyancy and do not have swimbladders like teleosts, so reaching a 
certain depth requires high swimming energy. If the blue shark's body size is small, it will be challenging to reach the most profound areas because the hydraulic lift is small in proportion to the size of the fish[3].

Table 2. The swimming layer and depth temperature of several tuna species from previous studies.

\begin{tabular}{llllll}
\hline \multirow{2}{*}{ Species } & \multicolumn{2}{c}{ Swimming Layer (m) } & \multicolumn{2}{c}{ Temperature } & \multicolumn{2}{c}{ Remarks } \\
& Min-Max & Optimum & Min-Max & Optimum & (Reference) \\
\hline YFT & $35.15-299.04$ & $85.73-167.80$ & $12.51-26.96$ & $22.20-26.40$ & {$[11]$} \\
ALB & $35.15-299.05$ & $85.73-124.74$ & $12.51-26.97$ & $21.41-26.40$ & {$[11]$} \\
ALB & $118-341$ & $118-291$ & $11.10-20.47$ & $12.41-20.47$ & {$[12]$} \\
ALB & & $150-199$ & & $20-20.9$ & {$[13]$} \\
& & $193.97-$ & & & \\
BET & $92.23-470.12$ & 470.12 & $8.35-26.80$ & $8.35-15.30$ & {$[11]$} \\
BET & & $300-399$ & & $10-13.9$ & {$[13]$} \\
& & $190.15-$ & & & \\
SBT & $118.23-194.21$ & 194.21 & $14.99-22.59$ & $14.99-15.12$ & {$[11]$} \\
BSH & $75.18-445.46$ & $75.18-299.04$ & $9.0-26$ & $13-26$ & This Study \\
\hline
\end{tabular}

Description: YFT (yellowfin tuna), ALB (albacore), BET (bigeye tuna), SBT (southern bluefin tuna) and BSH (blue shark)

\section{Conclusion}

Blue sharks are dominantly vertically distributed in the thermocline area with an estimated depth of 70 to $300 \mathrm{~m}$, where $84 \%$ of the total blue shark catch is in that area. Only $16 \%$ of the blue sharks were caught below the thermocline (underlayer) with larger body size than blue sharks in the thermocline area.

\section{Suggestion}

We hope this research will be perfected with real-time environmental data from remote satellite sensing, so the research results are perfect for suitable habitat indexes and fish behaviors.

\section{References}

1. N.E. Kohler, P.A. Turner, J.J. Hoey, L.J. Natanson, R. Briggs, Col. Vol. Sci. Pap. ICCAT. 54, 4 (2002)

2. J. Mejuto, B.G. Cortez, A.R. Cartelle, Tagging-recapture activities of large pelagic sharks carried out by Spain or in collaboration with the tagging programs of other countries (IOTC, Seychelles, 2005)

3. S.E. Campana, Can. J. Fish. Aquat. Sci. 73, 10 (2016)

4. S.C. Clarke, M.P. Francis, L.H. Griggs, Review of shark meat markets, discard mortality and pelagic shark data availability, and a proposal for a shark indicator analysis (Ministry for Primary Industries, Wellington, 2013)

5. G.L. Jordaan, J. Santos, J.C. Groeneveld, PLoS One 15, 8 (2020)

6. G. Ishimura, M. Bailey, Fish. Sci. 79, 3 (2013) 
7. Y. Hiraoka, M. Kanaiwa, S. Ohshimo, N. Takahashi, M. Kai, K. Yokawa, Fish. Sci. 82, 5 (2016)

8. J.W. Mandelman, P.W. Cooper, T.B. Werner, K.M. Lagueux, Rev. Fish Biol. Fish. 18, 4 (2008)

9. E. Cortes, F. Arocha, L. Beerkircher, F. Carvalho, A. Domingo, M. Heupel, H. Holtzhausen, M.N. Santos, M. Ribera, C. Simpfendorfer, Aquat. Living Resour. 23, 1 (2010)

10. S.E. Campana, M. Fowler, D. Houlihan, W. Joyce, M. Showell, M. Simpson, C. Miri, M. Eagles, DFO Can. Sci. Advis. Sec. Res. Doc., 49 (2015)

11. A. Barata, D. Novianto, A. Bahtiar, Indones. J. Mar. Sci. 16, 3 (2012)

12. F. Rochman, W. Pranowo, I. Jatmiko, Indones. Fish. Res. J. 22, 2 (2017)

13. B. Nugraha, S. Triharyuni, J. Litbang Perikan. Indones. 15, 3 (2009)

14. J.J Vaudo, B.M. Wetherbee, A.D. Wood, K. Weng, L.A.H. Jordan, G.M. Harvey, M.S. Shivji, Mar. Ecol. Prog. Ser. 547, 163-175 (2016)

15. S. Andrzejaczek, A.C. Gleiss, L.K.B. Jordan, C.B. Pattiaratchi, L.A. Howey, E.J. Brook, M.G. Meekan, Sci. Rep. 8, 1 (2018)

16. D.M. Coffey, A.B. Carlisle, E.L. Hazen, B.A. Block, Sci. Rep. 7, 1 (2017)

17. N. Queiroz, N.E. Humphries, L.R. Noble, A.M. Santor, D.W. Sims, PLos One 7, 2 (2012)

18. G.A. Latumeten, F. Purwanti, A. Hartoko, MAQUARES. 2, 2 (2013)

19. L. Song, Z. Yu, Y. Zhou, The relationship between the thermocline and the catch rate of Thunnus obesus in the tropical areas of the Indian Ocean (IOTC, Seychelles, 2007) 